OPEN ACCESS

Edited by:

Avigdor Abelson,

Tel Aviv University, Israel

Reviewed by:

Hartvig Caspar Christie, Norwegian Institute for Water

Research (NIVA), Norway

Brian Silliman

Duke University, United States

*Correspondence:

Giuseppe Guarnieri

giuseppe.guarnieri@unisalento.it

Specialty section:

This article was submitted to

Marine Conservation

and Sustainability,

a section of the journal

Frontiers in Marine Science

Received: 22 November 2019

Accepted: 05 June 2020

Published: 04 August 2020

Citation:

Guarnieri G, Bevilacqua S,

Figueras $N$, Tamburello $L$ and Fraschetti S (2020) Large-Scale Sea

Urchin Culling Drives the Reduction

of Subtidal Barren Grounds

in the Mediterranean Sea.

Front. Mar. Sci. 7:519.

doi: 10.3389/fmars.2020.00519

\section{Large-Scale Sea Urchin Culling Drives the Reduction of Subtidal Barren Grounds in the Mediterranean Sea}

\author{
Giuseppe Guarnieri ${ }^{1,2 *}$, Stanislao Bevilacqua ${ }^{2,3}$, Neus Figueras ${ }^{4}$, Laura Tamburello ${ }^{2,5}$ and \\ Simonetta Fraschetti2,5,6

\begin{abstract}
${ }^{1}$ Department of Biological and Environmental Sciences and Technologies, University of Salento, Lecce, Italy, ${ }^{2}$ Consorzio Italy, ${ }^{4}$ Institut de Ciències del Mar (ICM-CSIC), Barcelona, Spain, ${ }^{5}$ Stazione Zoologica Anton Dohrn, Naples, Italy,

${ }^{6}$ Department of Biology, University of Naples Federico II, Naples, Italy
\end{abstract} \\ Nazionale Interuniversitario per le Scienze del Mare, Rome, Italy, ${ }^{3}$ Department of Life Sciences, University of Trieste, Trieste,
}

Increasing anthropogenic pressures are causing long-lasting regime shifts from highdiversity ecosystems to low-diversity ones. In the Mediterranean Sea, large expanses of rocky subtidal habitats characterized by high diversity have been completely degraded to the barren state due to the high grazing pressure exerted by sea urchins, which could persist for a long time. In several areas of the world, removal of sea urchins has been found to have a positive effect on the recovery of overexploited subtidal rocky habitats. This study assessed, for the first time in the Mediterranean Sea, the effects of extensive sea urchin culling on the recovery of subtidal reefs from the barren state. We tested this approach within a Marine Protected Area where a combination of oligotrophic conditions, general depletion of fish stocks, dramatically high sea urchin densities, and the large expanses of barren grounds caused by date mussel fishery have hampered the natural recovery of shallow rocky reefs. Culling intervention (through hammering) was carried out in spring 2015, covering an area of 1.2 hectares at about $5 \mathrm{~m}$ depth. The effects of sea urchin removal were monitored at regular intervals for a time span of 3 years and were compared with two control sites adjacent to the culling area. We documented a progressive reduction in the extent of barren grounds in the fully protected area after the intervention. Also, very low re-colonization of sea urchins was observed during the experiment, so that no additional extensive culling was necessary. Our findings suggested sea urchin culling as a promising practice, also considering the limited costs of the intervention. However, since the reduction in extent of barren grounds was largely driven by turf-forming algae, caution is needed in the interpretation of the outcomes in terms of restoration, and results are discussed considering the factors involved in the observed shift and the synergies to be carried out for a full recovery of the system.

Keywords: macrobenthic assemblages, patch dynamics, rocky reefs, sea urchin barrens, restoration 


\section{INTRODUCTION}

Habitat degradation, fragmentation, and loss are among the most dramatic consequences of the escalating anthropogenic pressures on natural systems (Tittensor et al., 2014; Haddad et al., 2015; Steffen et al., 2015) and usually imply significant changes in biodiversity and ecosystem functioning (Pereira et al., 2010; Bartlett et al., 2016). Global analyses showed unprecedented rates of decline at all levels of biological diversity (Butchart et al., 2010). Exacerbated by multiple and synergistic effects of climate change (Bozec and Mumby, 2015), human impacts are increasingly compromising the capacity of marine ecosystems to absorb recurrent perturbations (Nystrom et al., 2000; Gundersen and Pritchard, 2002; Folke et al., 2004), thus limiting the potential for natural recovery (Scheffer et al., 2001; Lotze et al., 2011). The ultimate result of this process is a substantial transition of ecological systems into less productive or otherwise undesired states that are often difficult to reverse, called regime (or phase) shifts (Scheffer et al., 2001; deYoung et al., 2008; Rocha et al., 2015). A continuing increase in these phenomena has been observed in marine ecosystems worldwide (Levin and Möllmann, 2015).

On temperate rocky reefs, one of the most frequent and persistent regime shifts is the transition from macroalgaldominated habitats to barren grounds as a result of sea urchin overgrazing (Silliman et al., 2013; Steneck and Johnson, 2013; Filbee-Dexter and Scheibling, 2014; Ling et al., 2015). Anthropogenic stressors may play a crucial role in triggering and maintaining this shift by eroding the resilience of macroalgal beds while increasing the persistence of sea urchin barrens (Ling et al., 2015). For instance, the depletion of populations of sea urchin predators caused by overfishing has been invoked as the main driver leading to kelp bed collapse in different regions of the world [e.g., Hagen and Mann, 1992 (Canada); McClanahan, 2000 (Africa); Shears and Babcock, 2003 (New Zealand); Ling et al., 2009 (Australia); Watson and Estes, 2011 (Alaska)].

In the Mediterranean Sea, Paracentrotus lividus (Lamarck) and Arbacia lixula (L.) are the most common sea urchins inhabiting shallow hard bottoms (Bulleri et al., 1999; Boudouresque and Verlaque, 2001) and are of paramount importance in ecological processes leading to the shift from habitats characterized by well-structured macroalgal canopies (e.g., dominated by Cystoseira species) to less complex barren grounds dominated by encrusting coralline algae (Bulleri et al., 2002; Bonaviri et al., 2011; Agnetta et al., 2015). Although many processes underlie the population dynamics of these two species (Hereu et al., 2012 and reference therein), reduced top-down control of their populations due to overfishing of their predators has been demonstrated to play a crucial role in determining the establishment of the degraded alternative state in sublittoral rocky reefs (Micheli et al., 2005; Guidetti and Sala, 2007; Hereu et al., 2008; Sala et al., 2012; Cardona et al., 2013). However, given the hysteretic behavior of subtidal macroalgal systems (Filbee-Dexter and Scheibling, 2014; Ling et al., 2015), barren-state conditions may persist for years despite the establishment of mitigation strategies [e.g., Marine Protected Areas (MPAs)] aimed at the recovery of adult sea urchin predators (Pinnegar et al., 2000; Babcock et al., 2010; Galasso et al., 2015). Understanding whether alternative management actions could be implemented in marine coastal systems to face this widespread phenomenon should be a priority.

Based on evidence for the positive effects of reducing sea urchin density on the recovery of overexploited subtidal rocky habitats (reviewed by Ling et al., 2015), the practice of systematic sea urchin culling on "incipient barrens" (i.e., spatially discrete areas $<10 \mathrm{~m}^{2}$ ) has been applied in some areas of the world, specifically for kelp restoration (e.g., Bernstein and Welsford, 1982; Leinaas and Christie, 1996; Sanderson et al., 2015; Tracey et al., 2015). This action can also represent an opportunity for the development of a sustainable economy (e.g., https://www. urchinomics.com) since sea urchins are considered a consumable fishery resource worldwide (Andrew et al., 2002; Grisolía et al., 2012; Fernández-Boán et al., 2014; Bertocci et al., 2018).

The present study represents the first attempt in the Mediterranean Sea to perform systematic large-scale sea urchin culling on "extensive barrens" (sensu Ling et al., 2015), i.e., over a scale of thousands of square meters of continuous bare rock. The restoration activity, developed within the framework of the EU H2020 project "Marine Ecosystem Restoration in Changing European Seas," is the scale-up of a pilot study carried out in the same area (Guarnieri et al., 2014), where the role of sea urchin removal in triggering the process of recovery of persistent barren grounds was highlighted at small spatial scale (tens of meters). The aim of this study was to assess: (1) The effectiveness of a large-scale culling intervention in maintaining the reduction of herbivore pressure on disturbed benthic assemblages; (2) The direction and time frame of the recovery of assemblages in barren grounds.

\section{MATERIALS AND METHODS}

\section{Study Area}

The study was carried out in the South West of Apulia (Italy) within the MPA of Porto Cesareo (Figure 1A), one of the largest Italian marine reserves (16654 ha). The coast is almost entirely characterized by a gently sloping calcareous rocky plateau that drops onto a sandbank starting from the isobath of $10 \mathrm{~m}$ depth. Large expanses of subtidal rocky reefs in the MPA and beyond its boundaries have historically been depleted by illegal date mussel (i.e., Lithophaga lithophaga) fishery (Fanelli et al., 1994; Fraschetti et al., 2001; Guidetti et al., 2003), as occurred in other areas of the Mediterranean Sea (Devescovi et al., 2005; Bevilacqua et al., 2006; Guidetti and Dulčić, 2007; Parravicini et al., 2010; Giakoumi et al., 2012). This fishing practice has been demonstrated to have a crucial role in triggering the process leading to seascape desertification (Airoldi and Beck, 2007). Recent studies highlighted that the effects of this destructive fishery (forbidden since 1988) on the shallow rocky sublittoral are clearly evident for many kilometers along the coast and, in spite of the establishment of the MPA in 1997, no significant signs of recovery have yet been observed. Here, the main factor

${ }^{1}$ www.merces-project.eu 


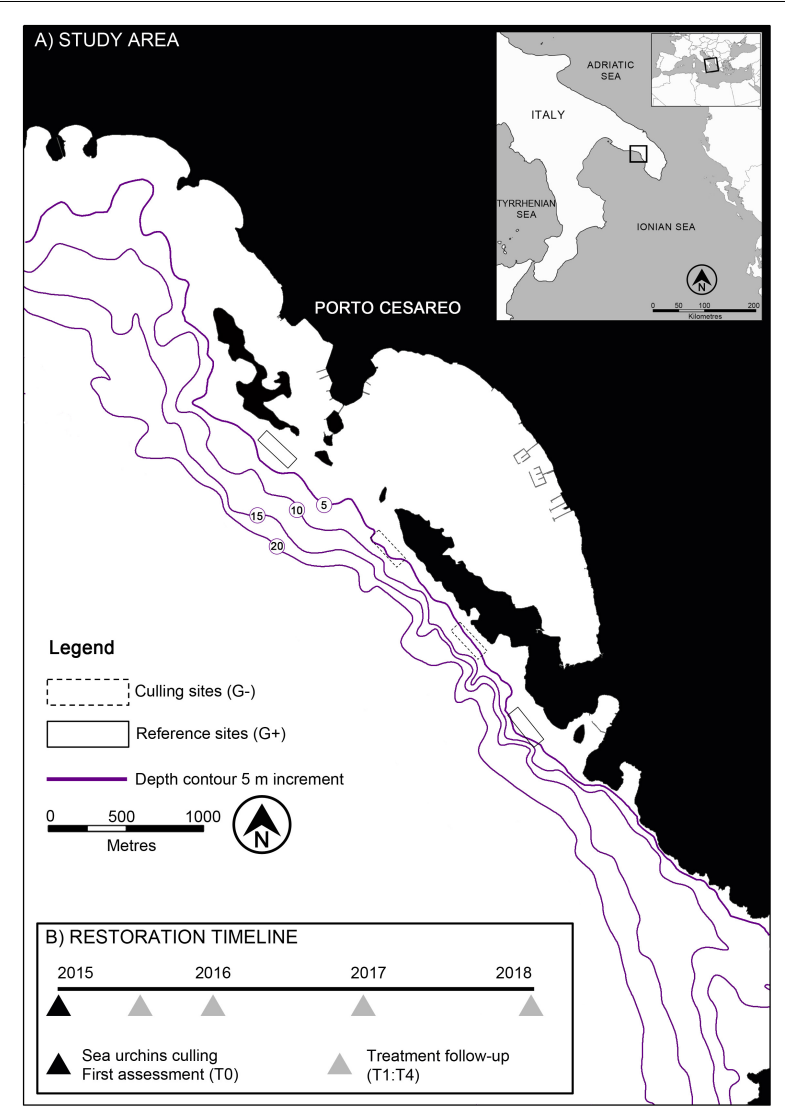

FIGURE 1 | (A) Study area and (B) timeline of the restoration intervention.

contributing to the inertia of the barren state is a combination of oligotrophic waters (Philippart et al., 2012), a general depletion of fish stocks (Guidetti et al., 2008; Giakoumi et al., 2017), and a dramatically high density $\left(\approx 20\right.$ individuals $\left.\mathrm{m}^{-2}\right)$ of sea urchins A. lixula and P. lividus (Guidetti et al., 2003), which are also prone to settle and/or recruit on reefs heavily impacted by date mussel fishery (Guidetti, 2011; Agnetta et al., 2013).

Based on preliminary surveys carried out along the 32 kilometers of rocky shore included in the MPA, we focused sea urchin culling within the no-take/no-access zone named "La Stream" $\left(40^{\circ} 14^{\prime} 35^{\prime \prime} \mathrm{N}-17^{\circ} 54^{\prime} 07^{\prime \prime} \mathrm{E}\right.$, Figure 1A) representing the area with the worst conditions in terms of desertification, with more than $60 \%$ of the plateau featuring barren grounds (Guarnieri et al., 2016). Our choice ensured, at the same time, the exclusion of any interference with the experiment due to human frequentation. Except for sparse patches colonized by the sponge Chondrilla nucula (covering just a few square meters) and some macroalgae (e.g., Dictyota spp., Halimeda tuna, Amphiroa rigida, and Padina pavonica), the barren grounds characterizing the study area were largely represented by bare rock dominated by encrusting coralline algae of the genera Peyssonnelia and Lithophyllum (Guidetti, 2011; Guarnieri et al., 2016).

A preliminary survey in the study area allowed the identification of two sites at 5-7 $\mathrm{m}$ depth (hereafter indicated as "G-") that were comparable in terms of extent (i.e., $6000 \mathrm{~m}^{2}$ each), low substrate morphological complexity (i.e., absence of ridges and depressions), and inclination $(<20 \%)$. Two control sites with similar conditions and extent (hereafter reported as "G+") were also included in the experiment (Figure 1A). This allowed the expected changes in the recovery rates caused by sea urchin removal to be separated from those potentially occurring during the time span of the intervention (i.e., 3 years) as a consequence of external long-term processes, such as natural fluctuations in grazer population demography and/or in patterns of distribution of benthic assemblages.

\section{Culling and Monitoring Activities}

The experimental intervention started in spring 2015. Sea urchins have a good dispersal distance (Paterno et al., 2017) and are thus able to colonize culled sites from adjacent areas. It was decided to perform culling before the typical reproductive periods in the study area (from spring to autumn) (Tenuzzo et al., 2012) to reduce larval supply from resident individuals. The systematic removal of sea urchins covered a total area of approximately 1.2 hectares. It was carried out in two sites with a linear extent of approximately $200 \mathrm{~m}$, and it was achieved by means of a belt transect method in which transect lines $(\approx 33$ culling transects for each site) were laid perpendicular to the coast following the $210^{\circ}$ course of a compass across the plateau $(\approx 5 \mathrm{~m}$ depth $)$ until its edge (transect length $\approx 30 \mathrm{~m}$ ). Divers positioned themselves on one side of the line and advanced in parallel, creating a "cleaning front" so that approximately $3 \mathrm{~m}$ from both sides of the lead core rope along that path remained free of sea urchins. Divers worked in parallel during 8 days of activity until the entire experimental sites (G-) were cleaned. All visible individuals were culled using hammers; a knife was employed to remove them from crevices. The experiment was carried out in accordance with the European Committee Council Directive (86/609/EEC) and Italian animal welfare legislation (D.L. 116/92). Species manipulated in this study are not critically endangered species, and according to Italian (D.L.vo 26/2014) and EU (Directive 63/2010) legislation on the care and use of experimental animals, the activity does not require approval by an animal ethics committee if carried out on-site. Moreover, the Porto Cesareo MPA Authority issued all permits needed for performing the fieldwork.

For each diver engaged in the activity, the number of sea urchins removed and the time spent was also recorded in order to provide useful information about the feasibility of the intervention. A total amount of $\approx 92500$ sea urchins were removed during the 8 days spent in the culling activities (Supplementary Table S1A) carried out at both sites. The number of divers per day who were engaged in the culling activity varied from a minimum of 5 up to 8 per day, each of them spending approximately 90 min underwater. A total of $84 \mathrm{~h}$ was devoted to the intervention, which corresponds to an average culling rate of $18.38 \pm 0.41$ urchins $\mathrm{min}^{-1}$ per diver. Regarding the sea urchins, A. lixula dominated on bare rocks, whereas both species co-occurred on sparse and small patches featuring the presence of C. nucula and macroalgae. The observed segregation was probably due to the high-energy hydrodynamic regime in the study area, which has been demonstrated to favor A. lixula, due to its higher resistance to dislodgment compared to $P$. lividus 
(Bulleri et al., 1999; Guidetti and Mori, 2005; Agnetta et al., 2013). This pattern further supports the results of other studies stressing the ability of A. lixula to maintain the barren state in the Mediterranean Sea (Bulleri et al., 2002; Privitera et al., 2008; Bonaviri et al., 2011; Bulleri, 2013; Piazzi and Ceccherelli, 2017).

The effects of sea urchin removals were monitored at regular intervals (i.e., 6, 12, 24, and 36 months after culling, hereafter indicated as time $[\mathrm{T}] 1-4)$ by mean of video and photographic surveys, covering a time span of 3 years (i.e., until June 2018, Figure 1B). Before the culling treatment, all experimental sites were surveyed in order to provide the baseline information (T0) about the status of barren grounds in terms of average sea urchin density, \% cover of bare rock, and structure of benthic assemblages.

Within each of the four sites (i.e., G- and G+), the average density of sea urchins was evaluated along three transects, each one covering a surface of $25 \times 1 \mathrm{~m}$ and randomly located tens of meters apart from each other. Along each transect, continuous underwater video footage was taken by means of a digital videocamera (Nikon Coolpix W300) held orthogonally downward at a standard distance from the bottom. From each of the three video transects, 10 frames (covering a sampling surface of $1 \mathrm{~m}^{2}$ ) were extracted at random to assess the $\%$ cover of barrens in the experimental sites. Since high image resolution was required for taxonomic identification of organisms, 10 randomly located surfaces of $16 \times 25 \mathrm{~cm}$ were also photographed along each transect. At each site, 30 photographic samples were taken at each time of sampling, yielding a total of 600 observation units. For each photographic sample, the cover of sessile organisms was estimated under magnification by superimposing a grid of 24 sub-quadrats on the entire photographed surface, and final values were expressed as a percentage. Organisms that were not easily identifiable at species level were grouped into higher taxonomic groups or into morphological groups (see Supplementary Table S2 for more details).

\section{Statistical Analyses}

A distance-based permutational multivariate analysis of variance (PERMANOVA, Anderson, 2001; McArdle and Anderson, 2001) was employed to test for differences in the structure of sessile assemblages between culling and control sites (i.e., G- and G+, respectively) across time. The analysis was based on Bray-Curtis dissimilarities calculated on untransformed data, and each term was tested using 4999 random permutations. The experimental design consisted of four factors: Time ( $\mathrm{Ti}, 5$ levels, fixed), Treatment (Tr, 2 levels, G- and G+, fixed and orthogonal), Site ( $\mathrm{Si}, 2$ levels, random, and nested in $\mathrm{Tr}$ ), and Transect (Ts, 3 levels, random, and nested in $\mathrm{Si}$ ) with $n=10$ replicates. Significant terms relevant to the hypothesis were investigated through post hoc pair-wise comparisons. Multivariate patterns of variation among the four different treatment combinations were visualized by non-metric multidimensional scaling (nMDS) of $\mathrm{Ti} \times \mathrm{Si}(\mathrm{Tr})$ centroids.

To identify taxa contributing most to temporal differences between culling and control sites, a canonical analysis of principal coordinates (CAP, Anderson and Willis, 2003) was also performed for the $\mathrm{Ti} \times \operatorname{Tr}$ interaction term, calculating the distance matrix among transects in culling and control sites in each time of sampling. Distinctness among $\mathrm{Ti} \times \operatorname{Tr}$ groups was assessed using leave-one-out allocation success (Anderson and Robinson, 2003). Individual taxa that might be responsible for any group differences seen in the CAP plot were investigated by calculating product-moment correlations of original variables (taxa) with canonical axes (e.g., Anderson and Willis, 2003). These correlations of individual variables with the two canonical axes $\left(r^{1}\right.$ and $\left.r^{2}\right)$ were then represented as lines in the CAP plot. Taxa were included in the plot only if an arbitrarily chosen value of correlation was exceeded (i.e., $\sqrt{r_{1}^{2}+r_{2}^{2}} \geq 0.3$ ). The same statistic was employed on a distance matrix based on Jaccard dissimilarities to investigate patterns of variation focusing on the assemblage composition.

ANOVA was employed to test for differences in the number of taxa and\% cover of barren areas between culling and control sites. ANOVA was also used to test for differences due to sea urchin removal in the abundance of the algae and invertebrate components of sessile assemblages. The percentage cover of the different algal taxa was aggregated into two categories (see Supplementary Table S2) according to their morphology and size of thallus, i.e., $<3$ and $>5 \mathrm{~cm}$ for turf-forming and erect algae, respectively (see Guarnieri et al., 2014 and reference therein). The same was done for invertebrates, which were grouped into a single category because of their limited coverage across experimental sites. Encrusting algae (e.g., Lithophyllum spp., Peyssonnelia spp.) were excluded from the univariate analyses since they represent a substrate suitable for the recruitment of a number of benthic organisms and can be considered equivalent to bare rock (Bulleri et al., 2012). For each response variable, univariate analyses were carried out following the same design as for multivariate analysis. Finally, ANOVA was employed to test for differences in sea urchin density by mean of a three-factor experimental design: Time (Ti, 5 levels, fixed), Treatment ( $\mathrm{Tr}$, 2 levels, fixed and orthogonal), and Site (Si, 2 levels, random, and nested in Tr) with $n=3$ replicates. Prior to analyses, the homogeneity of variance was examined using Cochran's $C$ test, and data were transformed if necessary. All univariate analyses were performed using GMAV version 5 software (University of Sydney, Australia), while multivariate analyses were carried out using the software PRIMER version 6, including the add-on package PERMANOVA+ (Anderson et al., 2008).

\section{RESULTS}

PERMANOVA on the assemblage structure based on BrayCurtis dissimilarities revealed a significant $\mathrm{Ti} \times \mathrm{Tr}$ interaction (Table 1), indicating an effect of sea urchin culling on the recovery of the assemblage in barren grounds. As indicated by pair-wise comparisons, significant differences across time only occurred at sites where sea urchins were removed, with clear signs of recovery 1 year (T2) after the beginning of the experiment. By contrast, no temporal difference was detected in the structure of assemblages within control sites, indicating that bare conditions persisted during the whole experiment. Temporal variations among sites according to the different 
TABLE 1 | Results of permutational multivariate analysis of variance (PERMANOVA) testing the effect of sea urchin culling on the structure of benthic assemblages.

\begin{tabular}{|c|c|c|c|c|}
\hline Source of variation & df & MS & Pseudo-F & $P($ perm $)$ \\
\hline Time $=\mathrm{Ti}$ & 4 & 39248 & 2.60 & 0.0068 \\
\hline Treatment $=\mathrm{Tr}$ & 1 & 217990 & 9.75 & 0.0002 \\
\hline Site $=\mathrm{Si}(\mathrm{Tr})$ & 2 & 22350 & 4.77 & 0.0190 \\
\hline Transect $=\mathrm{Ts}(\mathrm{Si}(\mathrm{Tr}))$ & 8 & 4688 & 3.17 & 0.0002 \\
\hline $\mathrm{Ti} \times \mathrm{Tr}$ & 4 & 31110 & 2.06 & 0.0338 \\
\hline $\mathrm{Ti} \times \mathrm{Si}(\mathrm{Tr})$ & 8 & 15121 & 2.79 & 0.0002 \\
\hline $\mathrm{Ti} \times \mathrm{Ts}(\mathrm{Si}(\mathrm{Tr}))$ & 32 & 5414 & 3.66 & 0.0002 \\
\hline Residuals & 540 & 1481 & & \\
\hline Total & 599 & & & \\
\hline \multicolumn{5}{|c|}{ Pair-wise test for term $\mathrm{Ti} \times \mathrm{Tr}$} \\
\hline $\mathrm{G}+$ & \multicolumn{4}{|c|}{ G- } \\
\hline $\mathrm{T} 0=\mathrm{T} 1=\mathrm{T} 2=\mathrm{T} 3=\mathrm{T} 4$ & \multicolumn{4}{|c|}{$\mathrm{T} 0=\mathrm{T} 1 \neq \mathrm{T} 2 \neq \mathrm{T} 3=\mathrm{T} 4$} \\
\hline TO & $\mathrm{T} 1$ & T2 & T3 & $\mathrm{T} 4$ \\
\hline $\mathrm{G}+=\mathrm{G}-$ & $\mathrm{G}_{+}=\mathrm{G}_{-}$ & $\mathrm{G}+\neq \mathrm{G}_{-}$ & $\mathrm{G}+\neq \mathrm{G}_{-}$ & $\mathrm{G}+\neq \mathrm{G}-$ \\
\hline
\end{tabular}

Analyses were based on Bray-Curtis dissimilarities (untransformed data), and each test was performed using 4999 permutations of appropriate units. Results of pairwise tests for the significant term $\mathrm{Ti} \times \mathrm{Tr}$ are reported below. G-, sea urchins culled; $\mathrm{G}+$, reference conditions.

treatments were portrayed in the nMDS plot (Figure 2A), which showed a progressive segregation between culling and control sites over time. CAP analysis showed that the observed changes in the structure of assemblages between G- and G+ were mostly driven by changes in the abundance of macroalgae components (Figure 2B), such as dark and green filamentous algae (DFA and GFA, respectively), articulated corallines (AC), A. rigida and Liagora viscida (belonging to the category of turfforming algae), Dictyotales, Laurencia spp. Cystoseira compressa, P. pavonica, and Wrangelia penicillata (belonging to erect macroalgae). By contrast, invertebrates [encrusting bryozoans (EB) and red sponges (ERS), together with Didemnidae, the group of calcareous tube worms (CTW), and the anthozoa Balanophyllia europaea] and encrusting calcareous rhodophytes (i.e., ECR and Peyssonnelia spp.), which are typical of barren habitats, mostly contributed to differentiated assemblages within the sites where sea urchins were not removed. Assemblage composition did not differ over time for either control or culling sites (Supplementary Table S3). Also, no difference in taxon composition was detected between treatments at the beginning and at the end of the experiment, indicating a similar composition of assemblages at culling and control sites during the entire duration of the experiment (Supplementary Figure S1 and Supplementary Table S3).

ANOVA on sea urchin density detected a significant $(F=1120$, $P<0.001)$ effect of culling in reducing the sea urchin population at culling sites compared to control sites. This reduction was consistently maintained during the whole duration of the experiment (Supplementary Table S1B). At the end of the experiment, sea urchins at culling sites $\left(\mathrm{G}_{-}\right)$were approximately $75 \%$ less abundant than at the beginning (i.e., from $9.16 \pm 1.02$ to $2.30 \pm 0.17$ individuals $\mathrm{m}^{-2}$ at $\mathrm{T} 0$ and $\mathrm{T} 4$, respectively). A reduction in sea urchin density was observed at $\mathrm{G}+$ during the

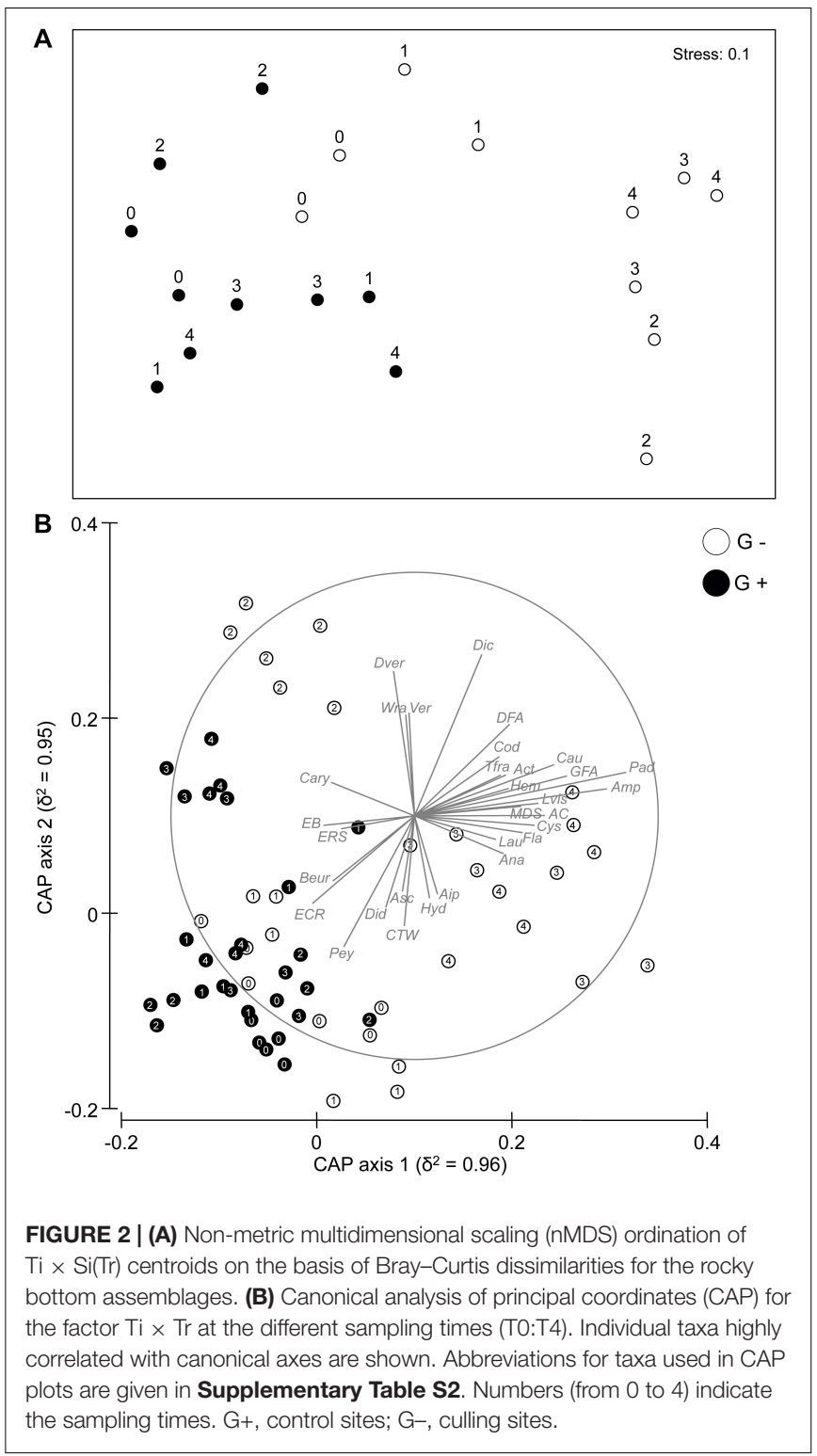

experiment, although control sites showed consistently higher sea urchin densities than culling sites (Figure 3).

The results of ANOVA (Table 2) showed a progressive reduction of the extent of barren grounds at culling sites through time (Figure 4A), as indicated by the significant interaction term $\mathrm{Ti} \times \mathrm{Tr}$. No difference was detected in terms of species richness (Figure 4B). Instead, ANOVA detected a significant increase in total cover for both turf-forming algae and erect macroalgae at culling sites during the experiment (Figures 4C,D). No differences between treatments were detected for invertebrates.

\section{DISCUSSION}

The understanding of mechanisms able to drive the recovery trajectories of barren grounds is critical for the development of widescale management strategies aimed at reverting the state of 


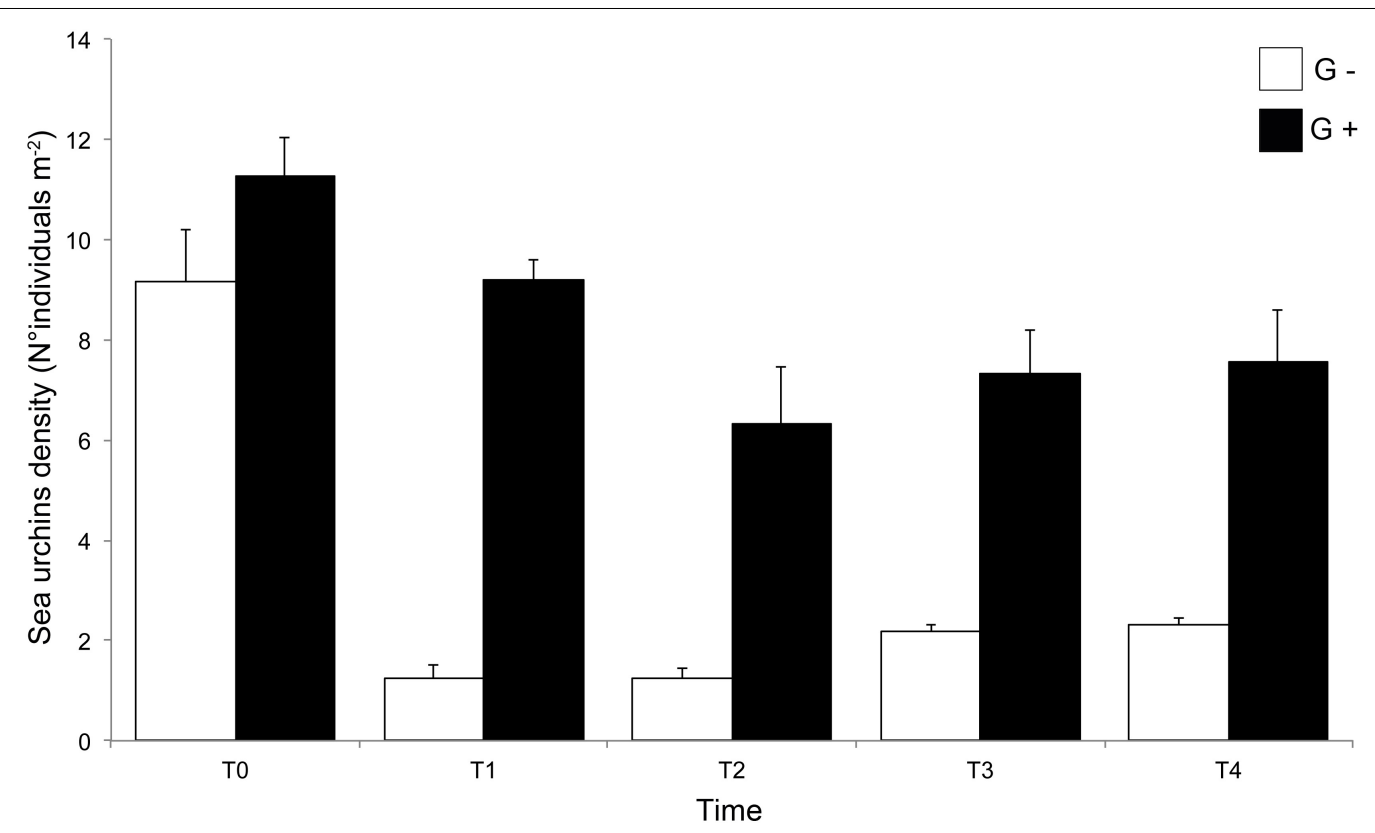

FIGURE 3 | Mean sea urchin density ( \pm SE, $n=6$ ) recorded at each time of sampling (T0:T4). G+, control sites; G-, culling sites.

TABLE 2 | Summary of ANOVA testing the effect of sea urchin culling on species richness (no. of taxa), percentage cover of bare rock, and the three main categories characterizing the surveyed assemblages (i.e., turf-forming algae, erect algae, and invertebrates) across time.

\begin{tabular}{|c|c|c|c|c|c|c|c|c|c|c|c|}
\hline \multirow[t]{2}{*}{ Source of variation } & \multirow[t]{2}{*}{ df } & \multicolumn{2}{|c|}{ No. of taxa } & \multicolumn{2}{|c|}{ Barren $\%$ cover } & \multicolumn{2}{|c|}{ Turf-forming algae } & \multicolumn{2}{|c|}{ Erect macroalgae } & \multicolumn{2}{|c|}{ Invertebrates } \\
\hline & & $\boldsymbol{F}$ & $P$ & $\boldsymbol{F}$ & $P$ & $F$ & $P$ & $\boldsymbol{F}$ & $P$ & $F$ & $P$ \\
\hline $\mathrm{Ti}$ & 4 & 1.48 & & 6.77 & & 5.15 & & 6.01 & & 0.54 & \\
\hline $\operatorname{Tr}$ & 1 & 2.14 & NS & 49 & * & 37.61 & * & 28.56 & * & 2.23 & NS \\
\hline $\mathrm{Si}(\mathrm{Tr})$ & 2 & 9.67 & $\star \star$ & 4.01 & NS & 2.30 & NS & 5.89 & * & 1.62 & NS \\
\hline $\mathrm{Ts}(\mathrm{Si}(\mathrm{Tr}))$ & 8 & 3.05 & & 4.05 & & 4.37 & & 3.70 & & 3.19 & \\
\hline $\mathrm{Ti} \times \mathrm{Tr}$ & 4 & 0.46 & NS & 4.03 & * & 3.25 & NS & 2.59 & NS & 2.7 & NS \\
\hline $\mathrm{Ti} \times \mathrm{Si}(\mathrm{Tr} r)$ & 8 & 10.35 & $\star \star \star ~$ & 3.02 & * & 2.23 & * & 2.57 & * & 1.24 & NS \\
\hline $\mathrm{Ti} \times \mathrm{Ts}(\mathrm{Si}(\mathrm{Tr}))$ & 32 & 4.15 & & 5.63 & & 6.44 & & 3.70 & & 3.37 & \\
\hline Residuals & 540 & & & & & & & & & & \\
\hline Total & 599 & & & & & & & & & & \\
\hline \multicolumn{2}{|l|}{ Cochran's test $(C)$} & \multicolumn{2}{|c|}{0.0498 (NS) } & \multicolumn{2}{|c|}{0.0483 (NS) } & \multicolumn{2}{|c|}{0.0730 (NS) } & \multicolumn{2}{|c|}{0.0640 (NS) } & \multicolumn{2}{|c|}{0.0434 (NS) } \\
\hline Transformation & & \multicolumn{2}{|c|}{ None } & \multicolumn{2}{|c|}{ None } & \multicolumn{2}{|c|}{ None } & \multicolumn{2}{|c|}{ None } & \multicolumn{2}{|c|}{ Square root $(x+1)$} \\
\hline
\end{tabular}

Only tests relevant to the hypotheses are reported. NS, not significant; for other abbreviations, see Table 1. ${ }^{*} P<0.05$, ${ }^{* *} P<0.01,{ }^{* * *} P<0.001$.

these degraded habitats (Ling et al., 2015). In addition, there is a need to diversify restorative approaches, which could be carried out simultaneously or sequentially in disturbed areas (Possingham et al., 2015; McDonald et al., 2016). Assisted habitat regeneration (sensu Elliott et al., 2007) implies human-mediated interventions aimed at reducing the effects of specific stressors. When combined with other forms of passive restoration (e.g., conservation measures), it can be considered an effective strategy for rebuilding ecosystem resilience by enhancing the recovery of degraded ecosystems (Suding, 2011; Possingham et al., 2015; Geist and Hawkins, 2016).

Our study showed that, 36 months after sea urchin removal, significant changes had occurred in the structure of benthic assemblages as a consequence of the systematic removal activity carried out at the target sites (Supplementary Figure S2). A progressive contraction of barren extent was observed, with a reduction in bare substrate of $50 \%$ at T4 (2018) in favor of macroalgal stands. To our knowledge, this is the first largescale experiment demonstrating that local recovery of discrete areas characterized by "extensive barrens" (i.e., thousands of $\mathrm{m}^{2}$ of bare rock) within a relatively short time span can be feasible. At the end of the experiment, two wide areas of $6000 \mathrm{~m}^{2}$ showed an overall increase in both erected and turfforming algae. This result supports previous evidence on the potential of control measures aimed at reducing sea urchin abundance in an attempt to restore the vegetative component of overgrazed temperate rocky reefs (Ling et al., 2010; Bonaviri et al., 2011; Tracey et al., 2015; Piazzi and Ceccherelli, 2019). 


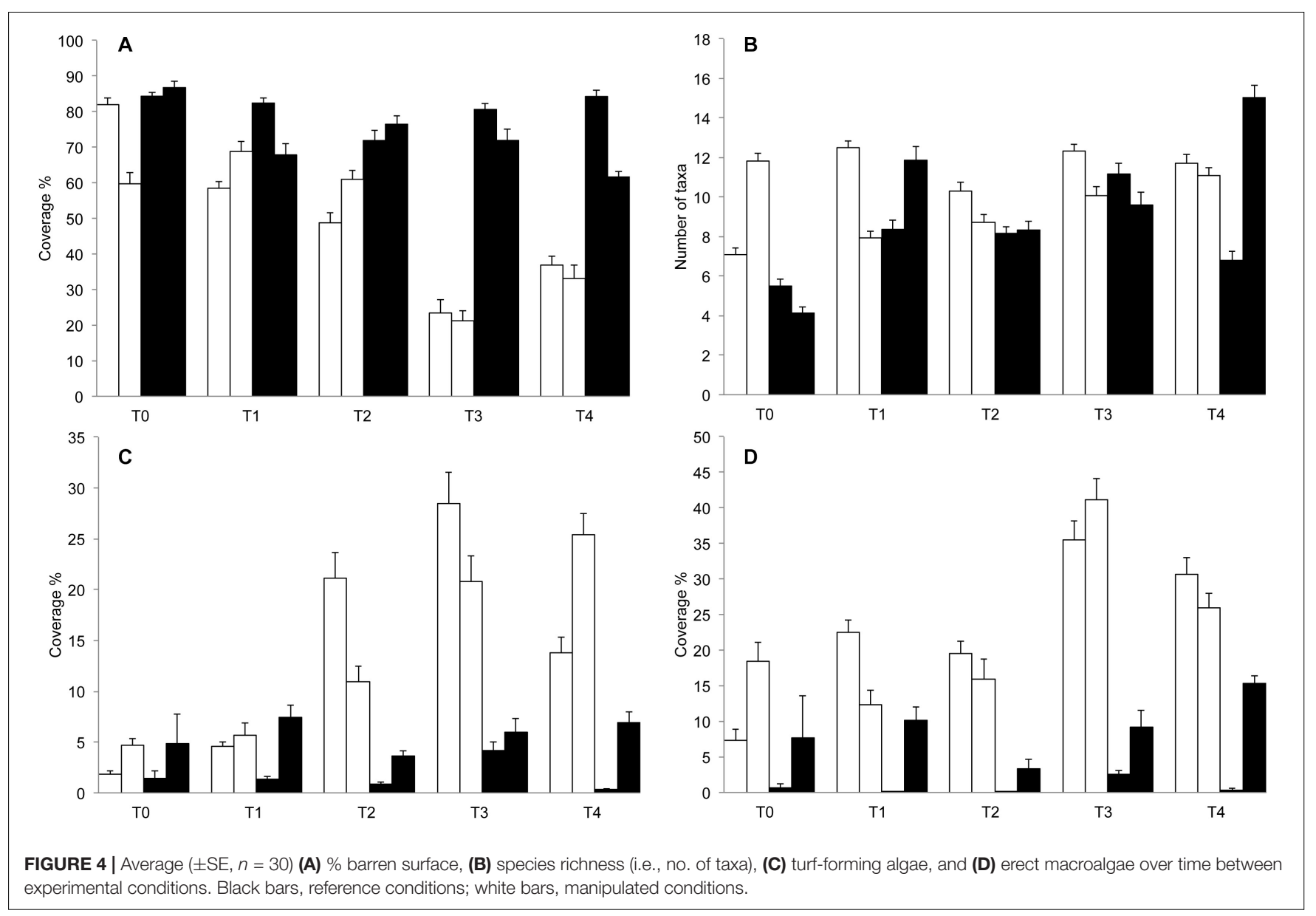

However, it is worth noting that the intervention was only conducive to a shift from one alternative state to another, without returning to the "healthy" conditions of the subtidal rocky reefs of the Mediterranean Sea (Sala et al., 2012; Thiriet et al., 2016). Actually, no difference was detected in the diversity and in the overall assemblage composition between culling and control sites, indicating that recovery trajectories did not reflect differences in the number of taxa nor in species composition between G- and G+. Differences were due, rather, to the increased relative abundance of macroalgal taxa, which were originally present in sparse, small, and isolated patches, generally in combination with the sponge C. nucula (Guarnieri et al., 2016). The observed increase in the algal component in culling areas was mostly driven by short (i.e., $<10 \mathrm{~cm}$ ) thallus species (e.g., Dictyotales, Laurencia spp., W. penicillata, and $P$. pavonica). These taxa are typical of shrubland-like habitats or turfs (Connell et al., 2014), representing the intermediate states of temperate reef along a gradient of structural and functional complexity ranging from canopy-forming habitats to barren grounds (Thiriet et al., 2016). The condition reached 1 year after the initial treatment did not evolve further, as suggested by the lack of differences between $\mathrm{T} 3$ and T4. This temporal pattern supports recent concerns about the pervasive trend of the alternative state characterized by the dominance of turfs persisting once established, thus preventing the recovery of highly structured macroalgal forests (FilbeeDexter and Wernberg, 2018). Recruitment of habitat-forming species (i.e., Cystoseria and Sargassum species) was not observed in the culling sites within the timeframe of the study, and the contribution of the invertebrates to sessile assemblages, in terms of overall abundance, was still very limited and comparable to control sites at the end of the experiment. The observed re-colonization pattern was consistent with the outcomes of other studies, which stressed the importance of context in terms of habitat arrangement (e.g., Piazzi and Ceccherelli, 2017, 2019) and water trophic status (Boada et al., 2017) in driving the trajectories of recovery. When extensive barren areas and the absence of patches of canopy-forming algae combine with oligotrophic conditions, small, fast-growing, and opportunistic algae are able to take advantage of the high free space availability of barren grounds (Airoldi, 2000). Life history and physiological traits allow this algal guild to outcompete, also through vegetative regeneration, other important functional groups. The ultimate consequence is the local disappearance of species with complex life cycles and slow rates of growth and recruitment, such as the majority of sessile invertebrates (Watling and Norse, 1998; Bevilacqua et al., 2006) or the canopy-forming species of the genus Cystoseira, which are also 
characterized by a limited spreading potential (Thibaut et al., 2015; Piazzi and Ceccherelli, 2019).

Several feedback processes might have impaired the recovery of sea urchin populations at culling sites. For the entire duration of the experiment, a very low re-colonization of sea urchins was observed, with average sea urchin density ranging from $1.25 \pm 0.28$ to $2.30 \pm 0.17$ individuals $\mathrm{m}-2$ at $\mathrm{T} 1$ and $\mathrm{T} 4$, respectively, so that no additional extensive removal of sea urchins was required during the time span covered by the study. The low rate of recruitment recorded after culling is a relevant and unexpected result. It highlights the importance of the spatial extent at which the sea urchin removal is conducted in reducing their population numbers. Moreover, it provides practical information about the feasibility of the intervention because it is conducive to a significant reduction of maintenance costs. On the other hand, this important outcome supports the results of recent global analyses (e.g., Filbee-Dexter and Scheibling, 2014; Ling et al., 2015) suggesting the existence of threshold levels in sea urchin density able to reverse the process of formation/maintenance of barren grounds (see Boada et al., 2017 for a special focus on the Mediterranean Sea).

A combination of system state-dependent stressors could have contributed to limiting the recovery potential of the sea urchin population and the observed long-lasting decrease in their density in manipulated sites (Ling et al., 2015). In particular, there is evidence that, for A. lixula (i.e., the sea urchin species dominating the study area), the availability of bare rock colonized by encrusting coralline algae represents an indispensable condition for settlement and the ensuing establishment of the high densities typical of barren grounds (Micheli et al., 2005; Guidetti and Dulčić, 2007; Privitera et al., 2011). Specific morpho-functional traits, proper to the species, make it particularly adapted to this type of habitat as compared to the co-occurring species (i.e., P. lividus) inhabiting Mediterranean shallow rocky reefs (Agnetta et al., 2013). Based on studies conducted in other areas of the Mediterranean Sea (e.g., Bulleri et al., 1999; Gianguzza et al., 2010; Privitera et al., 2011; Bonaviri et al., 2012), it is likely that the observed increase in algal coverage may have affected, both directly and indirectly, the processes occurring at the immediate post-settling stage, thus representing an important control of sea urchin populations in the manipulated areas: firstly, because of the development of unsuitable conditions for the settlement of sea urchins (Bulleri et al., 1999; Gianguzza et al., 2010; Privitera et al., 2011) and, also, by exposing settlers to higher predation rates as a result of a likely increase in mesofauna (e.g., decapod crustaceans) associated with macroalgal beds (Bonaviri et al., 2012). In addition, the intense hydrodynamism characterizing exposed rocky coasts further contributed to exacerbating the effects of the experimental treatment, given the high vulnerability of sea urchin juveniles to dislodgement (Guidetti and Mori, 2005). Finally, since adults can play a crucial role in reducing predation rates on juveniles through refuge provisioning (Zhang et al., 2011; Hereu et al., 2012; Clemente et al., 2013) or mesopredator consumption (Bonaviri et al., 2012), the survival of juveniles may also have been compromised by the extreme reduction of conspecific adults, as a direct consequence of the culling intervention.
Unfortunately, the lack of detailed information on potential variations in the background environmental conditions (e.g., thermal regime, spread of pathogens) during the experiment follow-up limits our understanding of the cause and effect relationships governing the population dynamics, at a local scale, beyond culling intervention. Since, in the control areas, a significant but slight reduction of sea urchin densities was also observed along the 3 years of the experiment, long-term investigations (at regional scale) in other areas historically characterized by the presence of barren grounds are necessary. Information on the size distribution of sea urchin populations should also be obtained to provide additional information about recruitment dynamics. This would allow the recovery intervention to be framed in a wider context, as well as taking into account a combination of acute or chronic environmental stressors, mostly related to climate change, such as intensified storms (Hereu et al., 2012; Medrano et al., 2019), and/or diseases (Privitera et al., 2012), which could play a crucial role in affecting the outcomes of culling interventions and associated costs.

There is wide consensus that coastal overgrazed habitats in shallow rocky reefs can represent an opportunity for the development and implementation of proactive restoration measures (Filbee-Dexter and Scheibling, 2014; Ling et al., 2015; Boada et al., 2017), even though the hysteresis effect governing the persistence of barren grounds might challenge the success of the interventions. This recognition stems from the general availability of baseline information related to causes (i.e., driving forces), tipping points, life history, and functional traits of species triggering the shift to and the maintenance of the degraded state typical of barren grounds. To date, the recovery of prey-predator interactions through the establishment of fishing restrictions (e.g., MPA) and/or the selective harvesting of sea urchins (Hill et al., 2003; Guidetti, 2006; Watanuki et al., 2010; Medrano et al., 2019) have been demonstrated to have the potential to revert the barrens into vegetated habitats. However, the effectiveness of these strategies could be compromised in sites where barren grounds are too extensive and/or environmental constraints (e.g., oligotrophic nutrient regimes, limited larval supply, high sea urchin recruitment rates) favor their persistence (e.g., Sanderson et al., 2015; Guarnieri et al., 2016). We demonstrated that sea urchin culling in the shallow subtidal zone represents a promising approach, thus supporting previous attempts in this direction in other geographic areas (i.e., Tracey et al., 2015). Our study also stressed that the success of restoration actions should be evaluated at adequate spatial scales to match the scale of disturbance leading to habitat degradation. This need is crucial also when considering shared targets aimed at halting or reversing widespread trends of biodiversity loss and habitat degradation (EU, 2011 [Target 2]; CBD, 2014 [Target 15]) through the restoration of at least the $15 \%$ of degraded ecosystems by 2020 , and the recent commitments of the UN on ecosystem restoration in the next decade ${ }^{2}$.

Taking into account that in the Mediterranean Sea the occurrence of barren grounds is expected to increase

\footnotetext{
${ }^{2}$ https://undocs.org/pdf?symbol=en/A/RES/73/284
} 
(Gianguzza et al., 2011), we anticipate that the results of the present study could represent a starting point for the implementation of long-term interventions carried out at large scale, to be adopted in areas affected by similar conditions. MPAs represent eligible sites where this type of intervention should be prioritized. However, complementary interventions, such as the transplantation of species with a critical ecological role, should be planned to enhance the restoration of shallow rocky reefs, considering the widely recognized importance of these habitats for the functioning of coastal ecosystems.

\section{DATA AVAILABILITY STATEMENT}

The datasets generated for this study are available on request to the corresponding author.

\section{AUTHOR CONTRIBUTIONS}

SF conceived and supervised all steps of the study. GG, SB, NF, and SF established the restoration action. All authors were involved in collecting data during the monitoring period and contributed to the draft and gave final approval for publication. GG and LT analyzed the data. GG led the writing of the manuscript.

\section{REFERENCES}

Agnetta, D., Badalamenti, F., Ceccherelli, G., Di Trapani, F., Bonaviri, C., and Gianguzza, P. (2015). Role of two co-occurring Mediterranean sea urchins in the formation of barren from Cystoseira canopy. Estuar. Coast. Shelf. Sci. 152, 73-77. doi: 10.1016/j.ecss.2014.11.023

Agnetta, D., Bonaviri, C., Badalamenti, F., Scianna, C., Vizzini, S., and Gianguzza, P. (2013). Functional traits of two co-occurring sea urchins across a barren/forest patch system. J. Sea Res. 76, 170-177. doi: 10.1016/j.seares.2012. 08.009

Airoldi, L. (2000). Responses of algae with different life histories to temporal and spatial variability of disturbance in subtidal reefs. Mar. Ecol. Prog. Ser. 195, 81-92. doi: 10.3354/meps195081

Airoldi, L., and Beck, M. W. (2007). Loss, status and trends for coastal marine habitats of Europe. Oceanogr. Mar. Biol. 45, 345-405. doi: 10.1201/ 9781420050943.ch7

Anderson, M. J. (2001). Permutation tests for univariate or multivariate analysis of variance and regression. Can. J. Fish. Aquat. Sci. 58, 626-639. doi: 10.1139/f01004

Anderson, M. J., Gorley, R. N., and Clarke, K. R. (2008). PERMANOVA+ for PRIMER: guide to software and statistical methods. Plymouth: PRIMER-E, 214.

Anderson, M. J., and Robinson, J. (2003). Generalized discriminant analysis based on distances. Aust. N.Z. J. Stat. 45, 301-318. doi: 10.1111/1467-842x.00285

Anderson, M. J., and Willis, T. J. (2003). Canonical analysis of principal coordinates: a useful method of constrained ordination for ecology. Ecology 84, 511-525. doi: 10.1890/0012-9658(2003)084[0511:caopca]2.0.co;2

Andrew, N. L., Agatsuma, Y., Ballesteros, E., Bazhin, A. G., Creaser, E. P., Barnes, D. K. A., et al. (2002). Status and management of world sea urchin fisheries. Oceanogr. Mar. Biol. Annu. Rev. 40, 343-425.

Babcock, R. C., Shears, N. T., Alcala, A. C., Barrett, N. S., Edgar, G. J., Lafferty, K. D., et al. (2010). Decadal trends in marine reserve reveal differential rates of change in direct and indirect effects. Proc. Natl. Acad. Sci. U.S.A. 107, 18256-18261. doi: $10.1073 /$ pnas.0908012107

Bartlett, L. J., Newbold, T., Purves, D. W., Tittensor, D. P., and Harfoot, M. B. J. (2016). Synergistic impacts of habitat loss and fragmentation on model ecosystems. Proc. Roy. Soc. B 283:20161027. doi: 10.1098/rspb.2016.1027

\section{FUNDING}

This research was funded by the project Marine Ecosystem Restoration in Changing European Seas (MERCES) of the European Union's Horizon 2020 Research (Grant Agreement No. 689518, http://www. merces-project.eu) and the EU Interreg MED AMAre project (http://msp-platform.eu/projects/amare-actions-marineprotected-areas).

\section{ACKNOWLEDGMENTS}

We thank I. Dalle Mura, C. Vaglio, and G. Farella for their help in the experimental setup. Thanks are due to the Marine Protected Area of Porto Cesareo for technical support and assistance during field activities.

\section{SUPPLEMENTARY MATERIAL}

The Supplementary Material for this article can be found online at: https://www.frontiersin.org/articles/10.3389/fmars. 2020.00519/full\#supplementary-material

Bernstein, B. B., and Welsford, R. W. (1982). An assessment of feasibility of using high-calcium quicklime as an experimental tool for research into kelp bed/sea urchin ecosystems in Nova Scotia. Can. Tech. Rep. Fish. Aquat. Sci. 968, 1-51.

Bertocci, I., Blanco, F., Franco, J. N., Fernandez-Boo, S., and Arenas, F. (2018). Short-term variation of abundance of the purple sea urchin, Paracentrotus lividus (Lamarck, 1816), subject to harvesting in northern Portugal. Mar. Environ. Res. 141, 247-254. doi: 10.1016/j.marenvres.2018. 09.017

Bevilacqua, S., Terlizzi, A., Fraschetti, S., Russo, G. F., and Boero, F. (2006). Mitigating human disturbance: can protection influence trajectories of recovery in benthic assemblages? J. Anim. Ecol. 75, 908-920. doi: 10.1111/j.1365-2656. 2006.01108.x

Boada, J., Arthur, R., Alonso, D., Pagès, J. F., Pessarrodona, A., Oliva, S., et al. (2017). Immanent conditions determine imminent collapses: nutrient regimes define the resilience of macroalgal communities. Proc. R. Soc. B 284:20162814B.

Bonaviri, C., Gianguzza, P., Pipitone, C., and Hereu, B. (2012). Micropredation on sea urchin as a potential stabilizing process for rocky reefs. J. Sea Res. 73, 18-23. doi: 10.1016/j.seares.2012.06.003

Bonaviri, C., Vega Fernández, T., Fanelli, G., Badalamenti, F., and Gianguzza, P. (2011). Leading role of sea urchin Arbacia lixula in maintaining barren state in southwestern Mediterranean. Mar. Biol. 158, 2505-2513.

Boudouresque, C. F., and Verlaque, M. (2001). "Ecology of Paracentrotus lividus," in Edible Sea Urchins: Biology and Ecology, ed. J. M. Lawrence (Amsterdam: Elsevier), 177-216. doi: 10.1016/s0167-9309(01)80 013-2

Bozec, Y. M., and Mumby, P. J. (2015). Synergistic impacts of global warming on the resilience of coral reefs. Philos. T. R. Soc. B 370:20130267. doi: 10.1098/rstb. 2013.0267

Bulleri, F. (2013). Grazing by sea urchins at the margins of barren patches on Mediterranean rocky reefs. Mar. Biol. 160, 2493-2501. doi: 10.1007/s00227013-2244-2

Bulleri, F., Benedetti-Cecchi, L., and Cinelli, F. (1999). Grazing by the sea urchins Arbacia lixula L. and Paracentrotus lividus Lam. In the northwest Mediterranean. J. Exp. Mar. Biol. Ecol. 241, 81-95. doi: 10.1016/s0022-0981(99) 00073-8 
Bulleri, F., Bertocci, I., and Micheli, F. (2002). Interplay of encrusting coralline algae and sea urchins in maintaining alternative habitats. Mar. Ecol. Prog. Ser. 243, 101-109. doi: 10.3354/meps 243101

Bulleri, F., Russell, B. D., and Connell, S. D. (2012). Context-dependency in the effects of nutrient loading and consumers on the availability of space in marine rocky environments. PLoS One 7:e33825. doi: 10.1371/journal.pone.0033825

Butchart, S. H. M., Walpole, M., Collen, B., Van Strien, A., Scharlemann, J. P. W., Almond, R. E. A., et al. (2010). Global biodiversity: Indicators of recent declines. Science 328, 1164-1168.

Cardona, L., Moranta, J., Reñones, O., and Hereu, B. (2013). Pulses of phytoplanktonic productivity may enhance sea urchin abundance and induce state shifts in Mediterranean rocky reefs. Estuar. Coast. Shelf Sci. 133, 88-96. doi: 10.1016/j.ecss.2013.08.020

CBD (2014). Strategic Plan for Biodiversity 2011-2020 and the Aichi Targets. Quebec: Secretariat of the Convention on Biological Diversity.

Clemente, S., Hernández, J. C., Montaño-Monctezuma, G., Russell, M. P., and Ebert, T. A. (2013). Predators of juvenile sea urchins and the effect of habitat refuges. Mar. Biol. 437, 579-590.

Connell, S. D., Foster, M. S., and Airoldi, L. (2014). What are algal turfs? Towards a better description of turfs. Mar. Ecol. Prog. Ser. 495, 299-307. doi: 10.3354/ meps 10513

Devescovi, M., Ozretic, B., and Ivesa, L. (2005). Impact of date mussel harvesting on the rocky bottom structural complexity along the Istrian coast (Northern Adriatic. Croatia). J. Exp. Mar. Biol. Ecol. 325, 134-145. doi: 10.1016/j.jembe. 2005.04.028

deYoung, B., Barange, M., Beaugrand, G., Harris, R., Perry, R. I., Scheffer, M., et al. (2008). Regime shifts in marine ecosystems: detection, prediction and management. Trends Ecol. Evol. 23, 402-409. doi: 10.1016/j.tree.2008.03.008

Elliott, M., Burdon, D., Hemingway, K. L., and Apitz, S. E. (2007). Estuarine, coastal and marine ecosystem restoration: confusing management and science - A revision of concepts. Estuar. Coast. Shelf S. 74, 349-366. doi: 10.1016/j.ecss. 2007.05.034

EU (2011). EU Biodiversity Strategy for 2020. Luxembourg: EU Publications Office.

Fanelli, G., Piraino, S., Belmonte, G., Geraci, S., and Boero, F. (1994). Human predation along Apulian rocky coasts (SE Italy) - Desertification caused by Lithophaga lithophaga (Mollusca) fisheries. Mar. Ecol. Prog. Ser. 110, 1-8. doi: 10.3354/meps110001

Fernández-Boán, M., Fernández, L., and Freire, L. (2014). History and management strategies of the sea urchin Paracentrotus lividus fishery in Galicia (NW Spain). Ocean. Coast. Manag. 69, 265-272. doi: 10.1016/j.ocecoaman. 2012.07.032

Filbee-Dexter, K., and Scheibling, R. E. (2014). Sea urchin barrens as alternative stable states of collapsed kelp ecosystems. Mar. Ecol. Prog. Ser. 495, 1-25. doi: $10.3354 /$ meps 10573

Filbee-Dexter, K., and Wernberg, T. (2018). Rise of turfs: a new battlefront for globally declining kelp forests. BioScience 68, 64-76. doi: 10.1093/biosci/bix147

Folke, C., Carpenter, S., Walker, B., Scheffer, M., Elmqvist, T., Gunderson, L., et al. (2004). Regime shifts, resilience and biodiversity in ecosystem management. Annu. Rev. Ecol. Syst. 35, 557-581. doi: 10.1146/annurev.ecolsys.35.021103. 105711

Fraschetti, S., Bianchi, C. N., Terlizzi, A., Fanelli, G., Morri, C., and Boero, F. (2001). Spatial variability and human disturbance in shallow subtidal hard substrate assemblages: a regional approach. Mar. Ecol. Prog. Ser. 212, 1-12. doi: 10.3354/meps212001

Galasso, N. M., Bonaviri, C., Di, Trapani F, Picciotto, M., Gianguzza, P., Agnetta, D., et al. (2015). Fish-seastar facilitation leads to algal forest restoration on protected rocky reefs. Sci. Rep. 5:12409.

Geist, J., and Hawkins, S. J. (2016). Habitat recovery and restoration in aquatic ecosystems: current progress and future challenges. Aquat. Conserv. 26, $942-$ 962. doi: $10.1002 /$ aqc. 2702

Giakoumi, S., Cebrian, E., Kokkoris, G. D., Ballesteros, E., and Sala, E. (2012). Relationships between fish, sea urchins and macroalgae: the structure of shallow rocky sublittoral communities in the Cyclades, eastern Mediterranean. Estuar. Coast. Shelf. Sci. 109, 1-10. doi: 10.1016/j.ecss.2011. 06.004

Giakoumi, S., Scianna, C., Plass-Johnson, J., Micheli, F., Grorud-Colvert, K., Thiriet, P., et al. (2017). Ecological effects of full and partial protection in the crowded Mediterranean Sea: a regional meta-analysis. Sci. Rep. 7: 8940 .

Gianguzza, P., Agnetta, D., Bonaviri, C., Di Trapani, F., Visconti, G., Gianguzza, F., et al. (2011). The rise of thermophilic sea urchins and the expansion of barren grounds in the Mediterranean Sea. Chem. Ecol. 27, 129-134. doi: 10. 1080/02757540.2010.547484

Gianguzza, P., Bonaviri, C., Milisenda, G., Bercellona, A., Agnetta, D., Vega Fernandez, T., et al. (2010). Macroalgal assemblage type affects predation pressure on sea urchins by altering adhesion strength. Mar. Env. Res. 70, 82-86. doi: 10.1016/j.marenvres.2010.03.006

Grisolía, J. M., López, F., and Ortúzar, J. (2012). Sea urchin: from Plague to market opportunity. Food Qual. Prefer. 25, 46-56. doi: 10.1016/j.foodqual.2012.01.004

Guarnieri, G., Bevilacqua, S., De Leo, F., Farella, G., Maffia, A., Terlizzi, A., et al. (2016). The challenge of planning conservation strategies in threatened seascapes: understanding the role of fine scale assessments of community response to cumulative human pressures. PLoS One 11:e0149253. doi: 10.1371/ journal.pone.0149253

Guarnieri, G., Bevilacqua, S., Vignes, F., and Fraschetti, S. (2014). Grazer removal and nutrient enrichment as recovery enhancers for overexploited rocky subtidal habitats. Oecologia 175, 959-970. doi: 10.1007/s00442-014-2944-4

Guidetti, P. (2006). Marine reserves re-establish lost predatory interactions and cause community changes in rocky reefs. Ecol. Appl. 16, 963-976. doi: 10.1890/ 1051-0761(2006)016[0963:mrrlpi]2.0.co;2

Guidetti, P. (2011). The destructive date-mussel fishery and the persistenceof barrens in Mediterranean rocky reefs. Mar. Pollut. Bull. 62, 691-695. doi: 10.1016/j.marpolbul.2011.01.029

Guidetti, P., and Dulčić, J. (2007). Relationships among predatory fish, sea urchins and barrens in Mediterranean rocky reefs across a latitudinal gradient. Mar. Environ. Res. 63, 168-184. doi: 10.1016/j.marenvres.2006.08.002

Guidetti, P., Fraschetti, S., Terlizzi, A., and Boero, F. (2003). Distribution patterns of sea urchins and barrens in shallow Mediterranean rocky reefs impacted by the illegal fishery of the rock-boring mollusc Lithophaga lithophaga. Mar. Biol. 143, 1135-1142. doi: 10.1007/s00227-0031163-Z

Guidetti, P., and Mori, M. (2005). Morpho-functional defences of Mediterranean Sea urchins, Paracentrotus lividus and Arbacia lixula, against fish predators. Mar. Biol. 147, 797-802. doi: 10.1007/s00227-005-1611-z

Guidetti, P., Milazzo, M., Bussotti, S., Molinari, A., Murenu, M., Pais, A., et al. (2008). Italian marine reserve effectiveness: does enforcement matter? Biol. Conserv. 141, 699-709. doi: 10.1016/j.biocon.2007. 12.013

Guidetti, P., and Sala, E. (2007). Community-wide effects of marine reserves. Mar. Ecol. Progr. Ser. 335, 43-56. doi: 10.3354/meps335043

Gundersen, L. H., and Pritchard, L. (eds) (2002). Resilience and the Behavior of Large scale Systems. Washington, DC: Island Press.

Haddad, N. M., Brudvig, L. A., Clobert, J., Davies, K. F., Gonzalez, A., Holt, R. D., et al. (2015). Habitat fragmentation and its lasting impact on Earth's ecosystems. Sci. Adv. 1:e1500052.

Hagen, N. T., and Mann, K. H. (1992). Functional response of the predators American lobster Homarus americanus (Milne-Edwards) and Atlantic wolffish Anarhichas lupus (L.) to increasing numbers of the green sea urchin Strongylocentrotus drobachiensis (Müller). J. Exp. Mar. Biol. Ecol. 159, 89-112. doi: 10.1016/0022-0981(92)90260-h

Hereu, B., Linares, C., Sala, E., Garrabou, J., Garica-Rubies, A., Diaz, D., et al. (2012). Multiple processes regulate long-term population dynamics of sea urchins on Mediterranean rocky reefs. PLoS One 7:e36901. doi: 10.1371/journal. pone.0036901

Hereu, B., Zabala, M., and Sala, E. (2008). Multiple controls of community structure and dynamics in a sublittoral marine environment. Ecology 89, 34233435. doi: 10.1890/07-0613.1

Hill, N. A., Blount, C., Poore, A. G. B., Worthington, D. G., and Steinberg, P. D. (2003). Grazing effects of the sea urchin Centrostephanusrodgersii in two contrasting rocky reef habitats: effects of urchin density and its implications for the fishery. Mar. Freshw. Res. 54, 691-700.

Leinaas, H. P., and Christie, H. (1996). Effects of removing sea urchins (Strongylocentrotus droebachiensis): stability of the barren state and succession 
of kelp forest recovery in the east Atlantic. Oecologia 105, 524-536. doi: 10. $1007 /$ bf00330016

Levin, P. S., and Möllmann, C. (2015). Marine Ecosystem regime shifts: challenges and opportunities for ecosystem-based management. Philos. Trans. R. Soc. B 370:20130275.

Ling, S. D., Ibbott, S., and Sanderson, J. C. (2010). Recovery of canopy-forming macroalgae following removal of the enigmatic grazing sea urchin Heliocidaris erythrogramma. J. Exp. Mar. Biol. Ecol. 395, 135-146. doi: 10.1016/j.jembe. 2010.08.027

Ling, S. D., Johnson, C. R., Frusher, S., and Ridgway, K. (2009). Overfishing reduces resilience of kelp beds to climate-driven catastrophic phase shift. Proc. Natl Acad. Sci. U.S.A. 106, 22341-22345. doi: 10.1073/pnas.0907529106

Ling, S. D., Scheibling, R. E., Rassweiler, A., Johnson, C. R., Shears, N., Connell, S. D., et al. (2015). Global regime shift dynamics of catastrophic sea urchin overgrazing. Philos. Trans. R. Soc. B 370:20130269. doi: 10.1098/RSTB.2013. 0269

Lotze, H. K., Coll, M., Magera, A. M., Ward-Paige, C., and Airoldi, L. (2011). Recovery of marine animal populations and ecosystems. Trends Ecol. Evol. 26, 595-605. doi: 10.1016/j.tree.2011.07.008

McArdle, B. H., and Anderson, M. J. (2001). Fitting multivariate models to community data: a comment on distance-based redundancy analysis. Ecology 82, 290-297. doi: 10.1890/0012-9658(2001)082[0290:fmmtcd]2.0.co;2

McClanahan, T. R. (2000). Recovery of a coral reef keystone predator. Balistapus undulatus, in east African marine parks. Biol. Conserv. 94, 191-198. doi: 10. 1016/s0006-3207(99)00176-7

McDonald, T., Gann, G. D., Jonson, J., and Dixon, K. W. (2016). International Standards for the Practice of Ecological Restoration - Including Principles and Key Concepts. Washington DC: Society for Ecological Restoration.

Medrano, A., Linares, C., Aspillaga, E., Capdevila, P., Montero-Serra, I., PagèsEscolà, M., et al. (2019). No-take marine reserves control the recovery of sea urchin populations after mass mortality events. Mar. Env. Res. 145, 147-154. doi: 10.1016/j.marenvres.2019.02.013

Micheli, F., Benedetti-Cecchi, L., Gambaccini, S., Bertocci, I., Borsini, C., Chato Osio, G., et al. (2005). Cascading human impacts, marine protected areas, and the structure of Mediterranean reef assemblages. Ecol. Monogr. 75, 81-102.

Nystrom, M., Folke, C., and Moberg, F. (2000). Coral reef disturbance and resilience in a human-dominated environment. Trends Ecol. Evol. 15, 413-417. doi: 10.1016/s0169-5347(00)01948-0

Parravicini, V., Thrush, S. F., Chiantore, M., Morri, C., Croci, C., and Bianchi, C. N. (2010). The legacy of past disturbance: chronic angling impairs long-term recovery of marine epibenthic communities from acute datemussel harvesting. Biol. Conserv. 143, 2435-2440. doi: 10.1016/j.biocon.2010. 06.006

Paterno, M., Schiavina, M., Aglieri, G., Ben Souissi, J., Boscari, E., Casagrandi, R., et al. (2017). Population genomics meet Lagrangian simultation: oceanographic patterns and long larval duration ensure connectivity among Paracentrotus lividus populations in the Adriatic and Ionian seas. Ecol. Evol. 7, 2463-2479. doi: 10.1002/ece3.2844

Pereira, H. M., Leadley, P. W., Proença, V., Alkemade, R., Scharlemann, J. P., Fernandez-Manjarrés, J. F., et al. (2010). Scenarios for global biodiversity in the 21 st century. Science 330, 1496-1501.

Philippart, C. J. M., Amaral, A., Asmus, R., van Bleijswijk, J., Bremner, J., Buchholz, F., et al. (2012). Spatial synchronies in the seasonal occurrence of larvae of oysters (Crassostreagigas) and mussels (Mytilusedulis/galloprovincialis) in European coastal waters. Estuar. Coast. Shelf. Sci. 108, 52-63.

Piazzi, L., and Ceccherelli, G. (2017). Concomitance of oligotrophy and low grazing pressure is essential for the resilience of Mediterranean subtidal forests. Mar. Pollut. Bull. 123, 197-204. doi: 10.1016/j.marpolbul.2017.08.061

Piazzi, L., and Ceccherelli, G. (2019). Effect of sea urchin human harvest in promoting canopy forming algae restoration. Estuar. Coast. Shelf. Sci. 219, 273-277. doi: 10.1016/j.ecss.2019.02.028

Pinnegar, J. K., Polunin, N. V. C., Francour, P., Badalamenti, F., Chemello, R., Harmelin-Vivien, M., et al. (2000). Trophic cascades in benthic marine ecosystems: lessons for fisheries and protected-area management. Environ. Conserv. 27, 179-200. doi: 10.1017/s0376892900000205
Possingham, H. P., Bode, M., and Klein, C. J. (2015). Optimal conservation outcomes require both restoration and protection. PLoS Biol. 13:e1002052. doi: 10.1371/journal.pbio.1002052

Privitera, D., Chiantore, M., Mangialajo, L., Glavic, N., Kozul, W., and CattaneoVietti, R. (2008). Inter- and intra-specific competition between Paracentrotus lividus and Arbacia lixula in resource-limited barren areas. J. Sea Res. 60, 184-192. doi: 10.1016/j.seares.2008.07.001

Privitera, D., Giussani, V., Isola, G., Faimali, M., Piazza, V., Garaventa, F., et al. (2012). Toxic effects of Ostreopsis ovata on larvae and juveniles of Paracentrotus lividus. Harmful Algae 18, 16-23. doi: 10.1016/j.hal.2012.03.009

Privitera, D., Noli, M., Falugi, C., and Chiantore, M. (2011). Benthic assemblages and temperature effects on Paracentrotuslividus and Arbacialixula larvae and settlement. J. Exp. Mar. Biol. Ecol. 407, 6-11.

Rocha, J., Yletyinen, J., Biggs, R., Blenckner, T., and Peterson, G. (2015). Marine regime shifts: drivers and impacts on ecosystems services. Philos. Trans. R. Soc. B 370:20130273. doi: 10.1098/rstb.2013.0273

Sala, E., Ballesteros, E., Dendrinos, P., Di Franco, A., Ferretti, F., Foley, D., et al. (2012). The structure of Mediterranean rocky reef ecosystems across environmental and human gradients, and conservation implications. PLoS One 7:e32742. doi: 10.1371/journal.pone.0032742

Sanderson, J. C., Ling, S. D., Dominguez, J. G., and Johnson, C. R. (2015). Limited effectiveness of divers to mitigate "barrens" formation by culling sea urchins while fishing for abalone. Mar. Freshw. Res. 67, 84-95.

Scheffer, M., Carpenter, S., Foley, J. A., Folke, C., and Walker, B. (2001). Catastrophic shifts in ecosystems. Nature 413, 591-596.

Shears, N. T., and Babcock, R. C. (2003). Continuing trophic cascade effects after 25 years of no-take marine reserve protection. Mar. Ecol. Prog. Ser. 246, 1-16. doi: 10.3354/meps 246001

Silliman, B. R., McCoy, M. W., Angelini, C., Holt, R. D., Griffin, J. N., and van de Koppel, J. (2013). Consumer Fronts, Global change, and Runaway Collapse in Ecosystems. Annu. Rev. Ecol. Evol. Syst. 44, 503-538. doi: 10.1146/annurevecolsys-110512-135753

Steffen, W., Richardson, K., Rockström, J., Cornell, S., Fetzer, I., Bennett, E., et al. (2015). Planetary boundaries: Guiding human development on a changing planet. Science 347:1259855. doi: 10.1126/science.1259855

Steneck, R. S., and Johnson, C. R. (2013). "Kelp forests. Dynamic patterns, processes and feedbacks," in 'Marine Community Ecology', eds M. Bertness, J. Bruno, B. Silliman, and J. Stachowicz (Sunderland, MA: Sinauer Associates), 315-336.

Suding, K. N. (2011). Toward an era of restoration in ecology: successes. failures, and opportunities ahead. Annu. Rev. Ecol. Evol. Syst. 42, 465-487. doi: 10.1146/ annurev-ecolsys-102710-145115

Tenuzzo, B. A., Zaccarelli, N., and Dini, L. (2012). The reproductive cycle of the commercial sea urchin Paracentrotus lividus (Lamark, 1816) (Echinodermata: Echinoidea) in the Ionian Sea. Ital. J. Zool. 79, 200-211. doi: 10.1080/11250003. 2011.626803

Thibaut, T., Blanfuné, A., Boudouresque, C. F., and Verlaque, M. (2015). Decline and local extinction of Fucales in the French Riviera: the harbinger of future extinctions? Mediterr. Mar. Sci. 16, 206-224.

Thiriet, P. D., Di Franco, A., Cheminée, A., Guidetti, P., Bianchimani, O., BasthardBogain, S., et al. (2016). Abundance and diversity of crypto- and necto-benthic coastal fish are higher in marine forests than in structurally less complex macroalgal assemblages. PLoS One 11:e0164121. doi: 10.1371/journal.pone. 0164121

Tittensor, D. P., Walpole, M., Hill, S. L. L., Boyce, D. G., Britten, G. L., Burgess, N. D., et al. (2014). A mid-term analysis of progress toward international biodiversity targets. Science 346, 241-244.

Tracey, S. R., Baulch, T., Hartmann, K., Ling, S. D., Lucieer, V., Marzloff, M. P., et al. (2015). Systematic culling controls a climate driven, habitat modifying invader. Biol. Invasions 17, 1885-1896. doi: 10.1007/s10530-0150845-z

Watanuki, A., Aota, T., Otsuka, E., Kawai, T., Iwahashi, Y., Kuwahara, H., et al. (2010). Restoration of kelp beds on an urchin barren: removal of sea urchins by citizen divers in southwestern Hokkaido. Bull. Fish. Res. Agen. 32, 83-87. 
Watling, L., and Norse, E. A. (1998). Disturbance of the seabed by mobile fishing gear: a comparison to forest clearcutting. Conserv. Biol. 12, 1180-1197. doi: 10.1046/j.1523-1739.1998.0120061180.x

Watson, J., and Estes, J. A. (2011). Stability, resilience, and phase shifts in rocky subtidal communities along the west coast of Vancouver Island. Canada. Ecol. Monogr. 81, 215-239. doi: 10.1890/100262.1

Zhang, Z., Campbell, A., Leus, D., and Bureau, D. (2011). Recruitment patterns and juvenile-adult associations of red sea urchins in three areas of British Columbia. Fish. Res. 109, 276-284. doi: 10.1016/j.fishres.2011. 02.014
Conflict of Interest: The authors declare that the research was conducted in the absence of any commercial or financial relationships that could be construed as a potential conflict of interest.

Copyright $\odot 2020$ Guarnieri, Bevilacqua, Figueras, Tamburello and Fraschetti. This is an open-access article distributed under the terms of the Creative Commons Attribution License (CC BY). The use, distribution or reproduction in other forums is permitted, provided the original author(s) and the copyright owner(s) are credited and that the original publication in this journal is cited, in accordance with accepted academic practice. No use, distribution or reproduction is permitted which does not comply with these terms. 